\title{
A política bancária do regime militar: o projeto de conglomerado (1967-1973) ${ }^{1}$
}

\author{
José Pedro Macarini ${ }^{2}$
}

\section{Resumo}

Este artigo examina a política bancária e financeira conduzida por Delfim Netto de 1967 a 1973, a qual se revestiu de características específicas. São examinadas as pronunciadas tendências à concentração no segmento dos bancos comerciais privados e a sua expansão para outras faixas de operação, formando conglomerados financeiros e, assim, alterando profundamente a estrutura projetada originalmente pela reforma de 1964. Ambos os processos estiveram vinculados à orientação particular da política econômica a partir de 1967, cujo sentido maior encontrou expressão na tentativa de implementar, no governo Médici, um projeto de conglomerado integrando banco e indústria, visando a consolidar um segmento de grandes empresas privadas nacionais. $\mathrm{O}$ artigo sistematiza evidência disponível acerca desse projeto estratégico - um capítulo importante da política econômica durante uma fase do regime militar.

Palavras-chave: Brasil - Política e Governo; Brasil - Política econômica; Bancos; Conglomerados.

\section{Abstract \\ The finance policy of military regime: the conglomerate project (1967-1973)}

This article discusses the banking policy led by Delfim Netto from 1967 trough 1973, which had special features. It is examined the tendency to banking concentration, very intense in those years, as well as the acute centralization process which led to the constitution of financial conglomerates, thus transforming the financial structure in a way not foreseen by the banking and financial reforms of 1964. Both processes reflected the new course of economic policy since 1967, having as its major objective to induce the formation of a new form of private capitalist organization - the conglomerate, integrating banking and industry -, which would led to the consolidation of a segment of big national private firms. The article seeks to collect the available evidence about that strategic project developed during a phase of the military regime.

Key words: Brazil; Military regime; Economic policy; Banking policy; Conglomerates. JEL E650.

\section{Introdução}

A política econômica do regime militar experimentou importantes inflexões, as quais devem ser atentamente examinadas como parte de um esforço de reconstituição daquele longo período histórico. Uma área em que isso ocorreu diz respeito ao tratamento dispensado aos bancos comerciais. Com efeito, durante os governos Costa e Silva (1967-1969) e Médici (1969-1974), com Delfim Netto

(1) Trabalho recebido em setembro de 2006 e aprovado em abril de 2007.

(2) Professor Assistente Doutor do Instituto de Economia da Universidade Estadual de Campinas (IE/Unicamp), São Paulo, Brasil. E-mail: <macarini@eco.unicamp.br>. 
no comando da política econômica, nota-se uma verdadeira inflexão na política bancária e financeira do regime. Seu resultado foi o surgimento de conglomerados financeiros, sob a liderança dos bancos comerciais, dando curso a um movimento totalmente distinto do imaginado durante o governo Castello Branco (1964-1967), com sua reforma financeira concebida no espírito da "especialização", a qual colocava aquelas instituições numa posição nitidamente secundária.

Em paralelo, observou-se também um agressivo processo de concentração bancária, com uma acentuada redução do número de casas matrizes e aumento da parcela de mercado controlada pelos cinco (ou dez) maiores bancos. Nesse caso, porém, embora o processo tenha se explicitado pós-1967, em matéria de política econômica houve uma linha de continuidade: o diagnóstico de um sistema bancário estruturalmente ineficiente e a crença na existência de economias de escala no setor levaram a uma política de estímulo à concentração, iniciada sob Campos-Bulhões e intensificada por Delfim Netto.

Para distinguir analiticamente esses dois processos emprego os termos concentração bancária para designar o processo de expansão por absorção e acumulação interna dos bancos comerciais e centralização financeira para o processo de diversificação que originou os conglomerados financeiros. Sua origem evidentemente está em Marx e na tradição marxista, mas o seu uso é feito aqui com uma certa liberdade que, espero, não represente uma violência contra os conceitos. De resto, existe uma ampla literatura (parte da qual será explicitamente utilizada) dedicada à concentração bancária, que terminou consagrando o uso desse termo no sentido adotado neste artigo. O importante, porém, é reconhecer que ambos os processos levam ao fortalecimento do poder econômico - no caso, dos grandes bancos comerciais. Isso coloca um novo aspecto nas vicissitudes experimentadas pela política econômica.

A inflexível implementação de um programa de estabilização durante o governo Castello Branco, conjuntamente com a política de "interdependência" expressa em um tratamento liberal concedido ao capital estrangeiro, fez com que o empresariado nacional experimentasse uma situação de debilitamento. Sintomaticamente, os governos seguintes passaram a colocar como uma importante prioridade o fortalecimento da empresa nacional, com diferentes desdobramentos concretos no plano da execução da política econômica. Durante o governo Médici essa diretiva articulou-se com o projeto Brasil Grande Potência: tal desiderato, projetado como meta para o ano 2000, refletiu igualmente a preocupação com os supostos riscos decorrentes de uma estrutura desbalanceada, com a empresa privada nacional revelando-se incapaz de atingir um status de relativa igualdade diante da filial estrangeira e da empresa estatal. Foi esse o pano de fundo que originou um capítulo obscuro e pouco estudado da política econômica daquele período, qual seja, a tese da desejabilidade (e viabilidade) de 
uma evolução mais ousada nos processos de concentração/centralização, contemplando-se a passagem para alguma forma de integração banco-indústria como mecanismo importante para assegurar a pretendida continuidade do crescimento acelerado com destacada participação de um segmento de grandes empresas privadas nacionais. Assim surgiu o projeto de conglomerado, componente importante da estratégia de desenvolvimento do governo Médici. Algumas medidas sinalizando esse propósito chegaram a ser tomadas; contudo, o projeto fracassou, sendo colocado à margem pelo governo Geisel (1974-1979). ${ }^{3}$

O objetivo deste artigo é o de sumariar a evolução observada na esfera financeira durante o período 1967-1974, explicitando o papel da política econômica (Seções 1, 2 e 3) e, sobretudo, sistematizar a evidência disponível acerca do projeto de conglomerado (Seção 4).

Utilizo com freqüência o discurso das autoridades e, sempre que possível, declarações de banqueiros. Esse é um recurso imprescindível para lograr uma aproximação às intenções da política econômica (note-se que, por vezes, elas são confirmadas ou mesmo mais bem explicitadas pelos atores do processo que personificam uma fração empresarial) bem como ao grau de congruência entre a política econômica e os interesses das frações empresariais envolvidas. No caso do projeto de conglomerado isso ganha uma dimensão imperativa. Com efeito, o esforço de reconstituição de um objeto dotado de características de uma "história oculta" - e uma vez fracassado, relegado ao esquecimento - obriga o investigador a buscar (e expor) todas as pistas dignas de consideração; daí o uso (que pode parecer excessivo para os desavisados) de citações de ministros, assessores, banqueiros, matérias do jornalismo econômico (onde o projeto é veiculado "em off' - por razões que apenas os conhecedores do submundo do poder entendem com clareza). Não há regra para executar com competência esse tipo de trabalho (o qual, supostamente, não se reduz a um amontoado de citações, recolhidas a esmo). $\mathrm{O}$ resultado final, em termos de trazer à luz algo que estava escondido ou apenas parcialmente vislumbrado, é o critério de avaliação do esforço empreendido. ${ }^{4} \mathrm{E}$

(3) Lessa (1998, p. 56-76) desenvolve uma sugestiva leitura da política econômica do PAEG ao II PND com ênfase nas inflexões que a retórica do regime sempre procurou ocultar. Aí é devidamente reconhecido o papel desempenhado pelo projeto de conglomerado. Ver, também, Tavares (1974, p. 208-263) para uma análise feita no auge dos processos descritos neste artigo, a qual evidencia como o projeto de conglomerado tornara-se um tema central no início da década de 1970.

(4) Esse método expositivo é justificado com muita propriedade por Ianni (1977, p. 9): "Há vários modos de dizer a verdade, ou procurá-la. Um deles... consiste em deixar que as pessoas envolvidas nas situações e problemas estudados utilizem as suas próprias palavras. Mesmo quando elas não estão em condições de ver claro, ou quando não podem dizer as coisas com clareza; mesmo nesses casos elas revelam dados significativos para a compreensão das situações e problemas. Em geral, no entanto, elas dizem o essencial.” Mas uma utilização eficaz desse método não se reduz a "mera articulação ou montagem de textos" (Ibid.). O investigador não pode perder de vista que o discurso também cumpre uma função de ocultamento - ver a respeito as oportunas reflexões de Lessa sobre a "história oficial" conforme manifestada no discurso da política econômica durante o regime militar (Ibid., p. 62-63). 
dada a natureza fugidia do objeto em questão, convém moderar a ambição de conhecimento. Este trabalho pretende avançar até onde permitido pelo tipo de material disponível (todas as pistas sistematizadas foram extraídas de fontes contemporâneas). Não há que se descartar a possibilidade de seu enriquecimento (ou qualificação) a partir de outros trabalhos de pesquisa apoiados em fontes alternativas (por exemplo, na linha da "história oral" ou "vivida", representada nos importantes depoimentos colhidos pelo CPDOC-FG).

\section{A reforma financeira de Campos-Bulhões e os bancos comerciais}

O intenso processo de desenvolvimento experimentado pelo Brasil durante a década de 1950, responsável pela emergência de uma estrutura industrial bastante diversificada, não foi acompanhado de um processo análogo na área financeira. Com isso, a despeito de um embrião de mudança representado pelo surgimento das sociedades financeiras, o sistema financeiro brasileiro exibia, no início da década de 1960, um perfil nitidamente insatisfatório do prisma das necessidades exigidas para a retomada do desenvolvimento (em crise desde 19621963). Um sistema financeiro privado com dominância esmagadora de bancos comerciais, operando no curto prazo e mobilizando recursos quase exclusivamente via depósitos à vista (os quais perfaziam mais de $90 \%$ dos haveres financeiros) não permitiria outra avaliação. A política econômica do regime militar atuou com desenvoltura nessa área, num esforço reformista de importância crucial na superação subseqüente da crise; outrossim, marcou decisivamente as características do desenvolvimento econômico brasileiro durante as duas décadas seguintes. ${ }^{5}$

A reforma financeira foi concebida a partir de uma percepção fortemente crítica acerca do desempenho dos bancos comerciais e de sua capacidade de reestruturar-se para responder adequadamente às novas necessidades de financiamento do desenvolvimento. Os bancos comerciais vinham se engajando em um voraz processo de abertura de novas agências - a forma utilizada para expandir a captação de depósitos (remunerados a níveis irrisórios, facultando a obtenção de um considerável spread); isso foi levado tão longe que terminou por engendrar uma situação de alto grau de ineficiência permeando todo o sistema bancário, expresso em elevados custos operacionais, fator estruturalmente impeditivo de uma redução das taxas de juros. A estabilidade dos preços, se lograda conforme o cronograma estabelecido pelo PAEG, explicitaria essa fragilidade profunda dos bancos comerciais. Por essa razão não se imaginava um papel destacado para os bancos. Os diferentes objetivos perseguidos pela reforma - ampliar a mobilização de poupança financeira, diversificar os mecanismos de Bulhões.

(5) Ver Silva (1980) e Almeida (1984) para uma apresentação detalhada das reformas de Campos- 
financiamento, reduzir a taxa de juros, etc. - seriam alcançados pela atuação agressiva (e eficiente) de outras instituições financeiras, enquanto os bancos comerciais permaneceriam restritos a seu tradicional campo de atividade, buscando ajustar-se a um novo ambiente de maior concorrência e menor inflação. Daí originou-se o desenho de um sistema especializado, dotado de uma variedade de instituições com funções específicas - inspirado no modelo americano (pós1933), por oposição ao modelo europeu de banco misto, i.e., que acumula diversas funções financeiras. Segundo Dênio Nogueira, ex-presidente do Banco Central de abril/1965 a março/1967, a opção pela especialização já tinha se tornado dominante em 1958, quando foi regulamentado o funcionamento das sociedades de crédito, financiamento e investimento (as financeiras), voltadas para o crédito de médio prazo, em vez de estender aos bancos comerciais essa função.

$\mathrm{Na}$ época... predominava um medo da insegurança motivado pelo fato de que 4 anos antes tiveram de ser fechados cerca de 20 bancos que se haviam complicado em investimentos a longo prazo. A hipótese de dar aos bancos atividades outras, além de sua rotina, era, por isso, repelida e os próprios banqueiros, na Comissão Consultiva de Política Bancária, desaconselharam a idéia de participar do prazo médio. ${ }^{6}$

Em suma, ainda que preservados em seu campo tradicional de operações e, naturalmente, com força política para fazer valer seus interesses ${ }^{7}-$, os bancos comerciais pareceriam destinados a cumprir um papel relativamente secundário no movimento futuro do capitalismo brasileiro. Quem tentasse captar o significado último da reforma, em seu momento inicial, não poderia deixar de reconhecer a função privilegiada atribuída ao banco de investimento ("designado deliberadamente como banco para lhe dar status", diria Bulhões Pedreira): alavanca financeira da acumulação de capital, pilar do futuro mercado de capitais (como seu agente "atacadista") e veículo da almejada internacionalização financeira. Nada mais distante da realidade que veio a se concretizar durante o ciclo expansivo 1967-1973. Em particular, o comportamento dos bancos comerciais desaguou no surgimento dos conglomerados financeiros, subvertendo

(6) Ver o seu depoimento reproduzido em Wanderley e Pimentel (1970, p. 12). Aloysio Faria, do Banco Real, confirma: "No passado, tivemos no Brasil... alguns problemas entre a SUMOC e alguns bancos brasileiros que se aventuraram em outros campos de atividade. Então, ficou aquela idéia de que o banco comercial não deveria dedicar-se a outra atividade, a não ser aquela para a qual havia sido criado. E essa idéia vigorou naturalmente por mais de uma dezena de anos. Daí a razão por que se procurou fundar empresas financeiras que atendessem a outras faixas do mercado, separadas dos bancos comerciais” (Banas, 19 abr. 1971).

(7) Foi assim que os bancos comerciais rapidamente impuseram uma modificação nos dispositivos originais da reforma, conforme relatado pelo jurista Bulhões Pedreira: "O banco de investimentos devia ter o monopólio dos CDB, o que lhe permitiria desenvolver o mercado de títulos de dívida a médio e longo prazo; mas os bancos comerciais fizeram uma grande pressão contra esse monopólio e seis meses ou um ano depois foram também autorizados a emiti-los e o prazo mínimo foi reduzido para seis meses, invalidando todo o esquema da lei". - "Para onde vai o sistema financeiro" (Boletim do IERJ, p. 4, jun. 1980). 
as intenções originais da reforma. Isso refletiu igualmente uma pronunciada mudança de enfoque da parte da política econômica, o que se observou já em 1967.

Com efeito, o governo Costa e Silva deu margem a uma inflexão na condução da política econômica, expressa no diagnóstico heterodoxo da inflação formulado por Delfim Netto e suas implicações em termos da adoção de uma linha expansionista nas áreas fiscal e, sobretudo, monetário/creditícia. ${ }^{8}$ Também no terreno da política financeira cabe identificar uma inflexão: já no primeiro ano de sua gestão, Delfim Netto executa um duplo movimento sinalizador do novo papel, agora protagônico, conferido aos bancos comerciais. Visto em perspectiva, o episódio mostra-se emblemático da mudança de postura das autoridades.

Um capítulo negligenciado da reforma fora a criação da Finame S.A., subsidiária do BNDE, porém com ampla participação de bancos privados nacionais e estrangeiros. Nela depositavam-se grandes esperanças: franquear o acesso à poupança externa, beneficiar-se da futura expansão do mercado de capitais e consolidar o papel nuclear dos bancos de investimento (através da institucionalização do mecanismo de repasse - seu criador referia-se à Finame como um "banco de bancos", um "banco misto de segunda linha"). Delfim Netto foi responsável pela desarticulação daquele esquema, impedindo que a idéia prosperasse. O ex-presidente do BNDE, José Garrido Torres, personagem central na montagem do projeto original, comentou esse episódio nos seguintes termos:

A entidade foi constituída, mas, infelizmente, com a mudança de governo não logrou registro no Banco Central (se é que registro precisava ser solicitado para algo criado por força de lei), porque a orientação das novas autoridades monetárias passou a ser outra, a ponto de se tentar o ridículo de tornar sem efeito a Finame S.A., criada por Decreto-Lei, por meio de mera resolução do Conselho Monetário (no Governo Castello Branco, a aprovação tinha sido unânime). O resultado é que o cadáver ficou insepulto até hoje e a experiência não foi daquelas que nos recomendam ao apreço e ao respeito do mundo, sobretudo dos bancos privados estrangeiros que acederam a nossas instâncias. ${ }^{9}$

Ao mesmo tempo, Delfim Netto introduzia um novo esquema, com a Resolução 63, possibilitando um canal de captação de recursos externos para repasse a tomadores domésticos, tendo como intermediários não apenas o BNDE e os bancos de investimento, mas também os bancos comerciais. Em 1967-1968 o potencial de mobilização de poupança externa era rigorosamente incerto. Mas essa dupla operação revelava uma distinta valoração do papel reservado aos bancos comerciais - os desdobramentos seguintes, na verdade, confirmariam tratar-se de uma radical metamorfose no tratamento dispensado pela política econômica aos bancos comerciais.

(8) Fishlow (1974) desenvolve essa questão de forma detalhada e persuasiva.

(9) Depoimento reproduzido em Wanderley e Pimentel (1970, p. 13). 


\section{0 movimento de concentração bancária e a política econômica}

A concentração bancária no Brasil é um processo que remonta ao final da década de 1940. A fase inicial da industrialização brasileira se fizera acompanhar de um prolongado período inflacionário e de um surto de atividades especulativas. Nesse ambiente multiplicaram-se as operações bancárias, realizadas por centenas de bancos, conformando uma estrutura dotada de características preocupantes: excessiva proliferação de pequenos bancos (exibindo uma débil estrutura de capital, quando não de valor apenas simbólico), predominância de operações especulativas, despreparo técnico e gerencial (expressando freqüentemente um caráter aventureiro), uma autofágica disputa por depósitos, etc. ${ }^{10}$

Assim, a concentração bancária observada de 1945 a 1964 - quando o número de bancos (exclusive Banco do Brasil) passa de 509 para 328 - refletiu em medida considerável a extrema fragilidade de uma parcela expressiva do sistema. Isso se depreende da circunstância de o processo ter se revestido do simples desaparecimento de bancos de reduzido porte - enquanto os bancos de maior solidez não revelavam interesse na sua absorção, a despeito de alguns incentivos oferecidos pela política econômica -, verificado com grande intensidade nas conjunturas de desinflação (1946-1948) ou de experimentos de estabilização (1954-1955 e 1958-1959). ${ }^{11}$

$\mathrm{Na}$ verdade, a diminuição do número de bancos é um indicador insuficiente para caracterizar com rigor aquele processo. Quando se examina a distribuição dos depósitos totais do sistema bancário (exclusive Banco do Brasil) durante a década de 1950, verifica-se que a fatia correspondente aos cinco maiores bancos experimentou um aumento (de 20,7\% para 22,4\%) apenas em 1958, evoluindo em seguida para um máximo de 25\% em 1960; e daí para frente declinaria continuamente, recuando para 20,9\% em 1967 (no caso dos dez maiores bancos, a parcela de 33,8\% nesse ano seria inclusive ligeiramente inferior ao registrado em 1950). ${ }^{12}$ Nesse sentido, a concentração bancária verificada nas duas décadas decorridas após a Segunda Guerra Mundial revestiu-se de características

(10) Um parecer técnico, de janeiro de 1959, redigido pela Comissão da Câmara de Deputados constituída para examinar o projeto de reforma bancária (em pauta desde junho de 1947), retratava a situação de uma forma contundente: "Os bancos nacionais vêm crescendo desordenadamente, subordinados a uma legislação obsoleta, falha de técnica, princípios e normas... Banqueiros improvisados, destituídos de experiência e dos necessários conhecimentos, surgiram por toda a parte. A aventura passou a substituir a prudência. A técnica foi suplantada pelo arrojo irresponsável. O crédito bancário deixou de ser o instrumento racional do progresso transformando-se em agente de negociatas de seus dirigentes, num verdadeiro crime à poupança privada e à riqueza do país" - citado por Carvalheiro (1982, p. 129-130). Uma descrição não menos severa das práticas disseminadas nos anos 1940 e 1950 é feita por um banqueiro de longa vivência. Ver Vidigal (1981, p. 82-84).

(11) Apenas nessas três conjunturas desapareceram cerca de 125 bancos. Para um exame desse período, ver Sochaczewski (1980) e Costa (1978).

(12) Ver Sochaczewski (1980, p. 137). Resultado semelhante, com base no índice de Herfindahl, foi evidenciado em Portocarrero de Castro (1981, p. 93-94). 
muito diferentes do processo desatado ao longo da gestão delfiniana nos governos Costa e Silva e Médici.

Coincidindo com a marcha do vigoroso ciclo expansivo desses anos, quando se combinaram uma notável intensificação da acumulação produtiva e financeira e o mais permissivo exercício das políticas monetária e creditícia (à exceção de um breve interregno em 1969), materializou-se um processo de concentração bancária de magnitude e alcance absolutamente inéditos até então. Alguns poucos dados bastam para ilustrar a dimensão do ocorrido.

O número de absorções de casas bancárias (predominantemente via incorporação, i.e., compra de controle acionário) manteve-se elevado durante todo o período, levando a uma redução do número de bancos comerciais privados nacionais de 188 em 1968 para 72 em 1974. E, ao contrário das duas décadas anteriores, não se tratou da quebra pura e simples de bancos pequenos ou mal administrados. Segundo a lúcida descrição de um grande banqueiro partícipe daquele movimento, os grandes bancos comerciais envolveram-se agressivamente numa estratégia expansionista, conduzidos por uma "visão de posicionamento futuro numa economia com perspectiva de expansão" (reproduzindo o típico padrão de comportamento da grande empresa oligopólica). Com isso, ele observou, “...um grande número de empresas pequenas está desaparecendo, não porque elas sejam antieconômicas ou ineficientes. Elas estão desaparecendo porque as grandes instituições pagaram por elas um preço, visando a posicionamentos futuros. Teriam, teoricamente, a possibilidade de sobreviver, mas o preço é que as derrubou". ${ }^{13}$

Por outro lado, a evolução da distribuição dos depósitos espelhou cristalinamente a tendência à concentração. Entre 1967 e 1976 a parcela correspondente aos cinco maiores bancos comerciais privados no total de depósitos do sistema (exclusive Banco do Brasil) saltou de 20,9\% para 34,2\% (um acréscimo de $64 \%$, impressionante se contrastado com o que ocorrera em período anterior). No caso dos dez maiores bancos, a participação nos depósitos foi de 33,8\% em 1967 e 48,3\% em 1976; note-se que o acréscimo na participação é quase inteiramente explicado pelo agressivo comportamento dos cinco maiores bancos (por esse critério). E o maior banco comercial privado (Bradesco) detinha em 1976 cerca de 12,1\% dos depósitos do sistema bancário (anteriormente a esse processo, em 1964, o maior banco comercial privado mobilizava tão-somente 4,2\% dos depósitos). Excluindo do cálculo o conjunto de bancos oficiais, o índice

(13) Olavo Setúbal (Visão, 29 abr. 1974, p. 90). A rede bancária incluía ainda 8 bancos estrangeiros, 4 federais e 24 estaduais. Ver Banco Central (1972, 1973, 1976). 
de concentração é muito maior: em 1977 os cinco maiores bancos privados respondiam por $44 \%$ dos depósitos totais. ${ }^{14}$

De maneira geral, as operações de absorção tiveram um papel destacado na expansão alcançada pelos grandes bancos. Com efeito, sua contribuição para o incremento desfrutado entre 1964 e 1976 na parcela dos depósitos totais foi de um terço nos casos do Bradesco e do Real, em torno da metade nos casos do Nacional, do Bamerindus e do Unibanco, e superior a $90 \%$ no caso do Itaú. No grupo dos dez maiores bancos, apenas dois tiveram uma expansão quase exclusivamente interna. ${ }^{15}$ Assim, o movimento de concentração foi instrumentalizado pelos interesses do grande capital bancário, alavancando a expansão das empresas líderes de uma estrutura oligopólica. E nesse processo a política econômica desempenhou um papel importante e explícito. ${ }^{16}$

O diagnóstico oficial relativo ao setor bancário enfatizava a sua elevada ineficiência operacional, em grande medida fruto da desordenada abertura de agências durante o longo período de inflação alta pré-1964. (O número total de agências cresceu de 1.565 em 1945 para 4.996 em 1959 e 7.005 em 1964.) Coerentemente, a política econômica procurou cercear esse comportamento. Já em 1965 foram suspensas as autorizações para instalações de novas dependências nesse ano e limitadas ao máximo de duas por banco as autorizações para 1966 (circular 18, de 07 de dezembro de 1965). Em seguida, as limitações seriam ampliadas, através da resolução 43 e da circular 67, de 28 de dezembro de 1966, as quais, além de restringir a duas por banco o número máximo de agências novas, exigiam o cumprimento de vários requisitos aos bancos interessados: aumento de capital, índice de imobilização, relação entre recursos próprios e depósitos não superior a um para dez (na ausência desse requisito legal, o índice médio observado era de um para quinze). Essa orientação restritiva prosseguiria, adquirindo um caráter absoluto a partir de 1970: sucessivas resoluções do Banco Central (141, de 23 de março de 1970, 200, de 20 de dezembro de 1971 e 266, de 15 de outubro de 1973) suspenderam a autorização de abertura de novas agências (exceto em casos específicos, tais como as transferências inter-regiões e as áreas pioneiras). É evidente que, dado o caráter nacional dos grandes bancos, exigindo a

(14) Silva (1980) sistematiza as estatísticas pertinentes e examina esse e outros indicadores de concentração. Uma análise com base no índice de Herfindahl mostra uma aceleração dramática da concentração no período 1965-1975 - ver Portocarrero de Castro (1981, p. 93-94).

(15) Carvalheiro (1982) explora esse aspecto do processo. Os bancos citados eram os seis maiores em 1976, pelo critério da magnitude dos depósitos (excluindo da classificação o Banco do Brasil e dois grandes bancos estaduais).

(16) Como lembrou o banqueiro Olavo Setúbal: "A criação de unidades muito grandes foi favorecida pelas autoridades, o que acelerou o processo. Esse favorecimento foi, basicamente, de ordem financeira e fiscal. O Banco Central permitiu determinadas vantagens fiscais para a absorção de unidades menores e menos eficientes, dentro da visão de que o sistema deveria criar unidades grandes, pela sua capacidade financeira, e com possibilidade operacional e segurança financeira consideráveis" (Visão, p. 90, 29 abr. 1974). 
ampliação da rede de agências para viabilizar o crescimento, essas medidas induziram aqueles bancos com estratégias mais agressivas a se engajarem no movimento de absorção de bancos menores. ${ }^{17}$

Em maior ou menor medida, a diretriz básica de estímulo à concentração foi favorecida por diferentes ações da política bancária. Por exemplo, ao procurar impor exigências de capital mínimo para a atividade bancária (resolução 204, de 20 de dezembro de 1971) bem como estreitar a sua relação com a magnitude dos depósitos. ${ }^{18}$ Uma menção especial deve ser feita a um aspecto certamente heterodoxo da política econômica do período: o tabelamento dos juros, introduzido pela resolução 114, de 07 de maio de 1969 e renovado sucessivamente, até 1973 sempre manejado com o propósito explícito de redução das taxas de juros. (Na administração Geisel, essa política prosseguiu até 1976, porém, num contexto de aceleração inflacionária, as taxas de juros nominais foram progressivamente elevadas pelo Banco Central.) Sem dúvida, essa política foi coerente com o conhecido diagnóstico da inflação (predominantemente de custos) formulado por Delfim Netto desde 1967, além de ser a opção compatível com um período em que o crescimento acelerado tornara-se uma explícita e real prioridade da política econômica. Contudo, há razões para especular que o tabelamento de juros tenha também contribuído para o desejado avanço da concentração bancária.

Em primeiro lugar é incerto o grau em que o tabelamento logrou efetivamente reduzir os juros do ponto de vista do agente tomador de empréstimo, dado que a prática de reciprocidades disseminada no período pode ter compensado em grande medida as diretrizes do Banco Central. ${ }^{19} \mathrm{E}$ com certeza o poder e a

(17) Um banqueiro avesso à diretriz oficial de concentração externaria uma opinião crítica a essa política no início de 1973: "A política atual, ao nivelar por baixo os bons e os maus bancos privados, impedindo-lhes a abertura de novas agências, com o objetivo de acelerar a concentração do sistema pelo estímulo indireto às aquisições ou fusões, que representam a única forma possível de um banco privado desenvolver sua rede de agências no momento, é extremamente rígida e contra-indicada... Estando já o sistema privado reduzido a um número razoável de bancos, e devidamente saneado, faz-se necessário conceder, pelo menos a bancos selecionados, maior flexibilidade para expansão de sua rede de agências" (Vidigal, 1981, p. 65-66). O diagnóstico oficial que informou o projeto de reforma financeira de Campos-Bulhões encontra-se em documentos do Planejamento (como o PAEG e o Plano Decenal) e em estudos de M. Simonsen realizados para subsidiar a ação do Planejamento. Uma excelente síntese desse material encontra-se em Almeida (1984, p. 8-17).

(18) Para um relato detalhado ver Conjuntura Econômica (jan. 1973, p. 49-55). Uma medida que parece não ter deixado registro legal foi a permissão para o parcelamento em quatro semestres das amortizações de ágios pagos pelo controle - segundo depoimento do diretor da área bancária do Banco Central, no artigo "Ao longo do tempo a concentração" (Jornal do Brasil, 31 mar. 1972). A medida não terá sido desprovida de importância se se tem em conta a verdadeira especulação na venda de cartas-patentes, captada pela imprensa especializada - ver, por exemplo, Banas Financeiro 1972-1973, p.128. Na vívida descrição do banqueiro Olavo Setúbal: "Houve brigas familiares para vender, porque o preço era tão alto que os membros não interessados na empres $a$ queriam realizar seu capital" (Visão, p. 94, 29 abr. 1974).

(19) Essa prática do sistema bancário foi registrada freqüentemente em todo o período 1969-1973, época em que as altas taxas de juros estiveram na mira do Banco Central. Ver, por exemplo, Carta Mensal APEC, 12 jul. 1969 (suplemento, p. II); Banas Financeiro, 1972-1973, p.142; Conjuntura Econômica, p. 48, jan. 1973. 
margem de manobra para impô-las a seus clientes eram diferenciados entre os agentes financeiros. Assim, a redução de juros tenderia a afetar mais seriamente os bancos de menor porte - tanto mais que a compensação através de um maior volume das operações de crédito, possibilitado pela política monetária/creditícia fortemente expansionista, também se distribuiria de forma desigual entre os bancos de diferentes tamanhos. Nessas condições, é possível especular, para uma mesma taxa nominal de juro (arbitrada pelo Banco Central) as taxas efetivas praticadas no mercado terão sido diferentes, criando um diferencial de rentabilidade em favor dos grandes bancos. Isso, convém não esquecer, num ambiente em que a disputa acirrada por cartas-patentes inflava o preço de venda.

De qualquer forma é certo que o tabelamento (baixista) dos juros foi fruto de condições econômicas muito especiais, permitindo a sua aceitação pelas empresas líderes do setor. Expansão crescente da oferta de crédito, dos repasses de recursos externos, das operações de crédito lastreadas em liberação dos depósitos compulsórios (caso do financiamento das exportações de manufaturados), introdução do open market ensejando ganhos com recursos retidos por até dois meses (recolhimentos do FGTS, do INPS, do IOF), remuneração de uma parcela crescente dos depósitos compulsórios (recolhidos em ORTN), juros livres ou substancialmente maiores nas operações de crédito pessoal - eis uma amostra das compensações concedidas aos bancos comerciais, tornando a redução nominal dos juros plenamente compatível com a preservação da rentabilidade do capital bancário.

A política bancária do período, ativamente engajada na promoção da concentração, perseguia um aumento da eficiência do sistema, refletido em menores custos operacionais. Isso era visto como pré-condição para o necessário declínio dos juros, em consonância com a pretendida trajetória de crescimento acelerado com desinflação. Essa perspectiva foi freqüentemente reiterada pelas autoridades. Um documento oficial de fins de 1969 anotava: "As taxas de juros reais do Brasil devem ser as mais altas do mundo, produzindo toda a sorte de dificuldades para os setores produtivos. Este é um problema que tem de ser enfrentado no nível institucional em que será colocado, sem precipitação, mas sem temores". ${ }^{20}$ Em 1971, durante o VIII Congresso Nacional de Bancos, Delfim Netto, após registrar o progresso já alcançado (uma queda marginal do custo por unidade de aplicação de 25,4 em 1969 para 23,2 em 1970), reiteraria a preocupação das autoridades:

Todos hão de compreender que isto determina uma taxa de juro absolutamente incompatível com o plano de funcionamento do sistema capitalista, se a taxa de inflação se reduzir de maneira um pouco mais acelerada do que temos conseguido. Macarini (2005).

(20) Programa da Política Econômica do Governo (p. 19). Para um exame desse documento, ver 
Isto coloca o problema do juro bancário como fulcro da possibilidade de redução da futura taxa de inflação neste país.

Reis Velloso, no mesmo tom, alertaria:

Não é demais repetir: se a estrutura de custos do sistema bancário é tal que o ponto de break even de grande número de estabelecimentos só é alcançado a uma taxa de juros elevada, isso constitui obstáculo a que se traga a taxa de inflação abaixo daquele nível, a curto prazo... O combate à inflação e a meta do desenvolvimento estão, pois, em jogo... É, de fato, importante que as reduções de taxa de juros se verifiquem... pela efetiva diminuição dos custos reais (Visão, 26 abr. 1971).

Em 1972, momento em que a desinflação voltou a ser colocada como um objetivo prioritário, Delfim Netto reafirmaria esse ponto: "O Governo tem a taxa de juros na mira e permanece muito atento aos desvios do processo. A fusão de bancos faz parte dessa estratégia" (Folha de São Paulo, 16 abr. 1972).

A almejada redução de custos seria subproduto das economias de escala decorrentes da concentração, cuja existência não parece ter sido objeto de qualquer questionamento por parte das autoridades. Delfim Netto, por exemplo, após o fracasso do episódio mais ousado de todo o processo (a fusão BradescoUnibanco), afirmaria categoricamente: "Existem realmente vantagens de escala no sistema bancário, isto é, o aumento do volume de transações concorre para a redução dos custos operacionais, e os que não entenderam isso ainda vão acabar entendendo de forma muito mais trágica". ${ }^{21}$ Também o Banco Central, em diferentes oportunidades, explicitaria o argumento da defesa da concentração como meio para, através das economias de escala, levar o sistema bancário a operar com menores custos operacionais. ${ }^{22}$

Como visto sumariamente acima, a concentração bancária avançou com vigor a partir de 1967, consolidando uma estrutura dominada por alguns grandes bancos. Contudo, conforme apontado pela literatura dedicada ao tema, as expectativas alimentadas pelas autoridades não se confirmaram: no mínimo, não há evidência de ganhos de escala durante as décadas de 1960 e 1970, quando o processo teve livre curso. ${ }^{23} \mathrm{E}$ é interessante observar que até mesmo os seus principais agentes, ainda quando vorazmente envolvidos no processo, demonstraram relutância em aceitar a tese oficial. Olavo Setúbal, do Banco Itaú, avaliava negativamente:

(21) Ver Jornal do Brasil (26 mar. 1973, p. 3).

(22) Ver, por exemplo, Banco Central (1972, p. 70).

(23) Ver Bouzan (1972, p.215-217), Portocarrero de Castro (1981, p.97), Carvalheiro (1982), Silva (1980). Em sentido contrário, porém limitando-se ao período pré-1964, ver Sochaczewski (1980). Interessante notar que a evidência relativa ao caso dos Estados Unidos, durante as décadas de 1980 e 1990, também levanta sérias dúvidas quanto à existência de economias de escala ou sua transmissão aos custos na atividade bancária. Ver Dymski (1999, cap. 6). 
Dentro dos estritos critérios dos autores americanos, nenhuma das fusões ou incorporações foi acertada. Os preços pagos e os custos operacionais não permitiriam, normalmente, um aumento imediato da rentabilidade... O ônus presente da fusão e da incorporação é muito grande e, então, o risco da empresa que se joga nesse caminho é muito grande, se ela não se conduzir bem: é fácil ter problemas muito sérios nesse esquema.

Aloysio Faria, do Banco Real, demonstraria ceticismo:

...eu acredito que o êxito de uma empresa depende um pouco, mas não fundamentalmente, do seu tamanho.

No mesmo tom, João Gustavo Haenel, do Finasa de Investimento:

Acredito que muitas das fusões são ineficientes e não conseguem remunerar o custo em que incorreram... Como se observou aqui, a concentração foi necessária, mas não indispensável... Houve muita ineficiência e muitos processos de fusão que poderiam ter sido evitados. ${ }^{24}$

\section{0 movimento de centralização e o surgimento dos conglomerados financeiros}

A reforma financeira de Campos-Bulhões abriu caminho para um intenso processo de acumulação financeira, reflexo da veloz expansão da intermediação financeira não bancária. $\mathrm{O}$ estoque de haveres financeiros não monetários como proporção do PIB evolui de irrisórios 1,6\% em 1964 para 13,5\% em 1970 e 23,7\% em $1974 .{ }^{25}$ As invejáveis possibilidades de lucratividade e expansão aí originadas não tardariam em despertar o interesse dos bancos comerciais. Isso fez emergir uma outra tendência característica do período pós-1967: a crescente expansão tentacular do capital bancário, invadindo esferas da intermediação financeira que originalmente lhe haviam sido vetadas. Assim, simultaneamente à concentração bancária, desenrolou-se um movimento de centralização financeira, responsável pelo surgimento de grandes grupos atuando nos diversos segmentos do mercado financeiro. Nada mais distante do projeto original da reforma de 1964.

Um dos segmentos de mais rápida expansão foi o crédito direto ao consumidor, reservado às financeiras. A retomada do crescimento a altas taxas da indústria de bens de consumo duráveis, em especial da automobilística, acoplou-se à forte expansão do $\mathrm{CDC}$, criando um horizonte firme de aplicação lucrativa aproveitado pelos bancos comerciais. Segundo a opinião de um banqueiro, o

(24) Ver Visão (29 abr. 1974); Banas Financeiro (1973-1974, p. 342); Vidigal (1981, p. 65, 94). Em sentido contrário, Nilo Medina Coeli, do Grupo Halles: "Não há dúvida... Concentrar significa reduzir custo. É fora de dúvida" (Banas, Brasil Financeiro 1973-1974, p. 344). Interessante que o banqueiro que menos dúvidas alimentava quanto à correção da política bancária delfiniana era o dirigente do primeiro conglomerado a implodir logo após a mudança de administração em 1974. Ver Assis (1983, cap. 1).

(25) Ver Silva (1980) e especialmente Tavares (1974), para um exame cuidadoso dessa dinâmica observada na esfera financeira. 
interesse por essa área de atuação já vinha de antes. ${ }^{26}$ E Delfim Netto, em um breve e notável estudo do final da década de 1950, já antecipara a tendência de crescente expansão no Brasil do crédito direto ao consumidor e, sobretudo, a futura absorção das financeiras pelos grandes bancos comerciais (através da compra de participação acionária), nos moldes do que se observava na Inglaterra. Nesse país, em 1958, o governo eliminou os controles praticados até então sobre as vendas em prestações, o que levou os mais importantes bancos ingleses a estenderem seu campo de operação abarcando também esse mercado (e o fizeram inicialmente comprando participação acionária nas companhias financeiras). Suas conclusões não deixam margem para dúvidas:

1. em primeiro lugar, por razões de fato, pensamos que as financeiras tenderão a desenvolver-se como na Inglaterra, ou seja, algumas grandes empresas ligadas diretamente ao setor bancário. Aqui como lá, entretanto, haverá lugar para um grande número de pequenas empresas; 2. em razão dessa integração é possível que as financeiras de grande porte levem vantagens de custo com relação às demais. ${ }^{27}$

O surgimento de um grande número de sociedades financeiras nos primeiros anos após a reforma - e, portanto, a percepção da necessidade de um movimento de concentração nesse segmento (com base na suposição de que instituições de grande porte têm vantagens de custo) - terá facilitado o avanço do capital bancário. Contudo, de importância decisiva foi a especialização das financeiras no $\mathrm{CDC}$, medida tomada em reação ao fracasso na tentativa de erradicação da prática do deságio nas emissões de aceites cambiais, coincidentemente implementada a partir de 1967. Os efeitos dessa medida foram diversos: ao amplificar o potencial expansivo do mecanismo de endividamento familiar, impulsionou a recuperação da economia; ao eliminar a concorrência até então exercida pelas financeiras no campo dos empréstimos para capital de giro, certamente beneficiou os bancos comerciais; igualmente suscitou a expansão dos bancos de investimento, ocupando o espaço deixado pelas financeiras. Mas o seu significado mais profundo foi o de inviabilizar operacionalmente as financeiras independentes: com efeito, o CDC, como crédito de massa, exigia a disponibilidade de uma ampla rede de agências, implicando um esforço de imobilização incompatível com a estrutura de capital dessas instituições. São justamente os dirigentes de conglomerados que chamam a atenção para esse ponto. Na avaliação de Olavo Setúbal:

O crédito direto ao consumidor, pela sua natureza, é um crédito de massa. Então, elas, que tinham uma estrutura muito pequena, porque trabalhavam na linha do

(26) "Surgida mais recentemente a indústria automobilística, uma nova e vasta faixa de grande rentabilidade, representada pelo financiamento da compra de veículos, escapou, sem razão lógica, ao âmbito dos bancos comerciais" (Vidigal, 1981, p. 91).

(27) Ver "O problema das financeiras no Brasil", de Antonio Delfim Netto, Luiz Mendonça de Freitas e Meyer Stilman, mimeo., s/d, p.36. O estudo é da época da discussão da Portaria 309, que regulamentou as financeiras. 
acceptance, foram obrigadas, por uma regulamentação, a trabalhar num outro campo. Isso as obrigou a ligar-se aos conglomerados financeiros ou às empresas comerciais. $^{28}$

Por outro lado, as autoridades abriram as portas para a conglomeração ao permitir a participação de instituições financeiras no capital de outras empresas, restrita porém à própria área financeira e a alguns segmentos do setor de serviços (circular 126, de 20 de março de 1969). E com a resolução 134, de 18 de fevereiro de 1970, eliminando algumas restrições quanto a prazo e deixando livres os juros incidentes nas operações de crédito pessoal (uma modalidade do crédito bancário indistinguível, na prática, do CDC das financeiras), a pressão da concorrência sobre as financeiras independentes tendeu a intensificar-se. Em paralelo, o febril surto especulativo no mercado de ações observado nos anos 1969-1971 estimularia os bancos comerciais a também incursionarem pela área de atuação dos bancos de investimento, corretoras e distribuidoras. O Banco Central arbitraria em favor dos bancos comerciais com a resolução 157, de 10 de setembro de 1970, permitindolhes participar de operações de underwriting do tipo best effort (modalidade em que a instituição financeira assumia apenas o compromisso de tentar colocar no mercado o máximo possível de ações, não se sujeitando a qualquer obrigação ou punição em caso de fracasso da operação). ${ }^{29}$

O movimento de centralização financeira avançou a uma velocidade extraordinária. Na entrada dos anos 1970 os conglomerados já despontavam como as instituições dominantes do sistema financeiro. Assim, na altura de 1971-1972 as

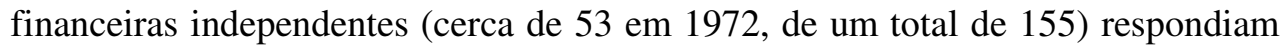
por tão-somente $12 \%$ a $15 \%$ do total das emissões de aceites cambiais; em contraste, as financeiras vinculadas a conglomerados sob controle de bancos comerciais abarcavam de $67 \%$ a $69 \%$ das emissões totais (confirmando plenamente as previsões sugeridas por Delfim Netto em seu estudo pioneiro). Um processo análogo ocorreu com os bancos de investimento: em 1978, de um total de 38 , restavam apenas quatro independentes, enquanto cerca de 23 estavam ligados a bancos comerciais. ${ }^{30}$

A reação dos bancos comerciais durante o processo de acumulação financeira pós-1967 transfigurou por completo a estrutura institucional projetada por ocasião da reforma. O conglomerado emergiu como uma realidade de facto, patrocinado pela política econômica, mas sem desfrutar de um estatuto legal próprio - não evoluindo para a figura do banco múltiplo, onde as várias

(28) Ver Visão (29 abr. 1974, p. 88). Justo Pinheiro da Fonseca, do Comind, tem o mesmo ponto de vista.

(29) O caráter conflitivo da matéria mereceu um comentário explícito da Carta Mensal APEC, (12 maio 1970, p. 4).

(30) Ver Banco Central (1972) e CVM (1979). 
instituições financeiras se dissolvem em departamentos especializados do banco comercial. Na descrição de um banqueiro:

Essa tendência natural recebeu primeiramente a tolerância e depois a expressa permissão das autoridades monetárias, conscientes da conveniência da prática. E dessa forma os conglomerados vão tendo a sua estrutura fortalecida e consagrada, num passo decisivo para a integração final dos sistemas financeiro e de mercado de capitais. A regra usual nos conglomerados é o controle acionário, pelo banco comercial que encabeça cada grupo, de instituições financeiras de outra natureza e de empresas complementares, nestas compreendidas as de prestação de serviços técnicos e administrativos, vedadas participações recíprocas que poderiam tornar ilusória a expressão do capital global (Vidigal, 1981, p. 94).

Haenel, do Finasa de Investimento, enalteceria o "pragmatismo brasileiro" que possibilitou "uma evolução, e não um retrocesso". Para ele:

Agora, o Brasil já encontrou um sistema que alia a compartimentação ao ecletismo das instituições financeiras: aparece o conglomerado, entidade abstrata, porque não existe na lei, mas de que todo mundo fala e sobre a qual até se legisla. O Conselho Monetário e o Banco Central falam nos conglomerados financeiros. É uma situação de fato (Visão, 29 abr. 1974, p. 86).

A evolução para o banco múltiplo era defendida por alguns banqueiros. De acordo com Haenel: “... o crédito ao consumidor nada mais é do que o crédito pessoal. Então, nem o raciocínio nem a prática repelem a possibilidade de, eventualmente, uma financeira vir a ser um departamento de um banco comercial. Está dentro da racionalidade do sistema". ${ }^{31}$ E ainda mais enfático, Justo Pinheiro da Fonseca, do Comind: "Acho inexorável: a financeira independente tende a desaparecer. A carteira de crédito pessoal dos bancos já se identifica, de maneira muito próxima, com as operações do consumidor final". ${ }^{32}$ Nessa matéria, entretanto, as autoridades não demonstrariam sintonia com as posições defendidas pelos bancos comerciais: em pelo menos uma oportunidade, Delfim Netto se manifestou contrário à idéia, duvidando que daí resultasse qualquer redução substancial de custo. ${ }^{33}$ Com isso, a regulamentação do banco múltiplo foi diferida por muitos anos, surgindo em um contexto totalmente distinto (final dos anos 1980).

(31) Ver Visão (29 abr. 1974, p. 86).

(32) Ver Visão (29 abr. 1974, p. 88). No mesmo sentido, porém admitindo a preservação de uma faixa de financeiras independentes, ver Vidigal (1981, p. 70).

(33) Ver Visão (07 nov. 1970, p. 50). Uma explicação plausível para essa negativa talvez estivesse em outro terreno; como sugerido por Roberto Teixeira da Costa: "O que impede a existência formal do multibanco no Brasil é a restrição ao acesso do capital estrangeiro ao sistema bancário comercial nacional. Como se permitiu ter até um terço de capital estrangeiro em banco de investimento, no momento em que se conglomerizar, haveria indiretamente participação estrangeira no banco comercial." Ver "Para onde vai o sistema financeiro" (Boletim do IERJ, jun. 1980). 


\section{Crescimento acelerado, capitalismo associado e o projeto de conglomerado financeiro-industrial}

Os movimentos paralelos de concentração e centralização na esfera financeira reforçaram sobremaneira o poder econômico dos grandes bancos. A sua consideração isolada não permite captar plenamente todo o seu real significado enquanto capítulos da política econômica do período. Nem só linha de ataque à inflação de custo, nem tampouco simples expressão direta dos interesses do grande capital bancário, embora isso fizesse certamente parte da história. Utilizando uma sugestiva formulação de Lessa (1998), a propósito do II PND da administração Geisel, o discurso oficial da política econômica do regime autoritário frequientemente exibiu um caráter truncado, ocultando divergências e minimizando mudanças de curso, componentes de um "projeto implícito" que a análise cuidadosa busca, sempre tentativamente, desvendar. Tal foi o caso da política bancária conduzida por Delfim Netto de 1967 a 1973, quando um particular projeto estratégico para o capitalismo brasileiro foi sendo paulatinamente germinado, sem jamais explicitar-se plenamente. De fato, como se depreende das evidências aqui coletadas, o fortalecimento do grande capital bancário, genuinamente nacional, terá sido pensado como um primeiro passo rumo à futura integração banco-indústria, dando nascimento à desejada grande empresa privada nacional.

Essa era uma preocupação do regime aflorada a partir dos desdobramentos da crise 1962-1967 que revelaram um pronunciado debilitamento do setor privado nacional. E com a recuperação pós-1967, mesmo crescendo, a empresa nacional parecia destinada a ocupar perenemente uma posição subordinada numa estrutura capitalista em que o Estado e a empresa multinacional despontavam como os atores principais. Situação incômoda na medida em que o regime demandava da política econômica não apenas a gestão cotidiana da economia mas igualmente a formulação de um projeto nacional. Este evoluiu, com o governo Médici, para um projeto de traços megalômanos - "Brasil Grande Potência". Assim, crescimento acelerado (a $10 \%$ a.a.) como objetivo prioritário, acompanhado de desinflação (pelo menos em 1972-1973) - mas, não menos importante, fortalecimento da empresa privada nacional como diretiva continuamente perseguida. $\mathrm{O}$ projeto implícito do conglomerado, de inspiração delfiniana, foi a mais importante tentativa, naquele período, de atender a essa demanda. Em contraste com o modelo "agrícola-exportador", outra peça da estratégia de desenvolvimento do governo Médici, o projeto do conglomerado sempre se manteve circunscrito no interior de uma área cinzenta, nebulosa mesmo. A limitada visibilidade impede a sua reconstituição definitiva; entretanto, há evidência suficiente confirmando que o projeto foi efetivamente perseguido. 
A primeira referência explícita à idéia data de 1969, por ocasião da controvérsia armada em torno da necessidade de redução das taxas de juros, apresentada então como um capítulo crucial da política econômica, definida logo após a edição do AI-5 em termos de um ataque frontal à inflação. Naquela oportunidade, Delfim Netto sinalizou a possibilidade de uma nova reforma institucional ao argumentar:

Toda a tradição da política bancária nacional é contra a integração entre o setor financeiro e o setor industrial, o que além de impedir a formação de grandes empresas capazes de absorver o progresso tecnológico e competir no exterior, desvincula o setor bancário do mundo da produção física. É evidente que neste campo é preciso agir com cautela, mas é evidente, também, que a cautela excessiva (com medo do monopólio ou da iliquidez) é muito prejudicial ao desenvolvimento de um capitalismo eficaz (Citado em Wanderley; Pimentel, 1970, p. 5).

Delfim investia, assim, contra a regulamentação estabelecida pela Lei 4.595, a qual proibia expressamente as instituições financeiras de concederem empréstimos às pessoas jurídicas nas quais mantivessem participação acionária superior a $10 \%$ do capital global. Não resta dúvida de que a manifestação de Delfim sugere uma rejeição da concepção liberal da reforma de 1964, constituindo um primeiro e discreto aceno do desejo de implementar uma reformulação na moldura do sistema bancário e financeiro. Mas a forma tímida como foi lançada, como se fora um "balão de ensaio" para testar o seu grau de receptividade, daria margem a diferentes interpretações. Alguns defenderiam a formação de holdings capitaneadas pelos bancos de investimento; outros propugnariam pela autorização às instituições financeiras em geral (portanto, também os bancos comerciais) para atuarem como centros financeiros de conjuntos empresariais. ${ }^{34}$

A proposta não logrou avançar após o seu lançamento. $O$ que não significa, de modo algum, que tivesse sido abandonada. Em um conhecido artigo do início do governo Médici dedicado à estratégia nacional de desenvolvimento, Delfim Netto identificaria, entre os objetivos fundamentais perseguidos, o de "estimular o fortalecimento de grandes empresas nacionais", acrescentando que uma das razões para acreditar no seu êxito residiria precisamente no "... fato de que o poder econômico é extremamente débil em termos nacionais, não tendo o empresariado tido tempo para produzir fortunas realmente significativas e sólidas, nem para obter a integração do setor industrial com o setor financeiro (o que,

(34) O debate também refletiu o primeiro momento de fascínio pelo "modelo japonês". Um observador privilegiado do episódio comentou: "Quando se pôs em debate... a hipótese de ser adotada no Brasil uma legislação bancária semelhante à do Japão - e, especialmente, possibilitar aos bancos de investimento a função de holdings de grupos financeiros e industriais com os quais pudessem operar - houve uma verdadeira corrida às cartas-patentes destas instituições... O exame dos fatores favoráveis e contrários a esta tese não permitiu - pelo menos até agora - a sua efetivação". Cf. C. A. Wanderley). "Começa a era dos superbancos para ampliar mercado financeiro" (Jornal do Brasil, 20 mar. 1970). Ver também Wanderley e Pimentel (1970, p.5 e 14-15). 
freqüentemente, os coloca em posições antagônicas)". ${ }^{35} \mathrm{O}$ recado, discreto sem dúvida, estava dado. A integração banco-indústria, substituindo o antagonismo eventual pela perpétua comunhão de interesses, devia ser olhada com cuidado na busca do poder econômico nacional, objetivo último da estratégia de desenvolvimento.

Durante o VIII Congresso Nacional de Bancos, em abril de 1971, a proposta seria renovada com ênfase. Delfim Netto apenas lembraria que, na estratégia de desenvolvimento em curso, "o setor privado é uma peça fundamental"; e faria uma convocação ao setor privado bancário "para que venha somar-se ao extraordinário esforço de mobilização que realiza toda a economia brasileira na construção de uma sociedade desenvolvida e livre". Coube ao presidente do Banco do Brasil, Nestor Jost, explicitar o conteúdo da convocação:

Deixa-nos, porém, algumas dúvidas a plena integração dos banqueiros brasileiros no processo evolutivo da política econômico-social do país... Acho, também, que os bancos poderiam voltar a participar da empresa. Tenho muitos exemplos, especialmente no Japão e na Alemanha. São duas economias que podem servir de exemplo, nos últimos tempos, onde os bancos participam ativamente com capital e com liderança na empresa... Seria necessário reformular a legislação. Mas que legislação é perpétua? Nós nos estamos transformando, diariamente. O Brasil de ontem não é o Brasil de hoje, e o de amanhã também não será o de hoje (Visão, 26 abr. 1971, p. 45-49).

Eis aí a integração banco-indústria abertamente proclamada. Os banqueiros privados chamados às falas por sua tradicional timidez empresarial, omissos diante da necessidade de afrontar riscos, um comportamento inadequado em face do "esforço de mobilização" capitaneado pela política econômica do "milagre". Olhai o exemplo do Japão e da Alemanha - essa a pregação oficial dos primeiros anos 1970. Reis Velloso, refletindo sobre o tema, chegaria a vislumbrar uma tipologia de instituições conglomeradas:

No Brasil, se considerarmos os efeitos da inflação no passado e as elevadas taxas de capitalização necessárias para manter um crescimento industrial acima de $10 \%$, o sistema financeiro vai ser chamado a atuar intensamente na aceleração da capitalização das empresas. Isso coloca o problema da tendência à formação de conglomerados, sejam do tipo puramente financeiro - associação de bancos comerciais, bancos de investimento e sociedades financeiras -, sejam do tipo voltado para a diversificação de investimentos, para colocação de excedentes de recursos de grupos empresariais e financeiros que se haviam concentrado em certo setor; sejam do tipo voltado para a integração de grupo financeiro com grupo industrial, especializado em determinada área. A escolha de rumo, nesse campo, deverá garantir o fortalecimento do empresariado nacional, dando-lhe melhor estrutura de capital, de forma compatível com a segurança do sistema financeiro. ${ }^{36}$

(35) Ver "Dêem-me o ano e não se preocupem com décadas". Jornal do Brasil (31 mar. 1970).

(36) Ver o discurso de Reis Velloso, divulgado pelo Ministério do Planejamento (1971). 
Não deixa de ser revelador o momento escolhido para a deflagração do projeto. Em 1971 a centralização financeira já havia avançado o suficiente para reduzir o peso específico dos bancos de investimento independentes na discussão quanto a qual instituição haveria de ser o núcleo do futuro conglomerado. E não menos importante, estava em andamento um impressionante boom bursátil, com sinais de uma possível firme ampliação do mercado primário de ações. É evidente que a consolidação do mercado de capitais, perseguida desde a reforma de 19641965, constituía um pré-requisito para a conglomeração, seja como fonte de recursos seja pela necessidade de uma prévia generalização do processo de abertura de capital. Aliás, isso foi reconhecido pelo próprio Delfim Netto, em julho de 1971, quando a Bolsa mergulhava no que veio a se tornar um irreversível movimento de baixa, suscitando decepção e perplexidade:

O governo continua dando seu apoio à construção de um sólido mercado de capitais. A consolidação desse mercado, absolutamente necessária para que seja possível desenvolver um sistema empresarial eficiente, constitui o primeiro passo para a grande reforma bancária que vamos realizar quando chegar o momento oportuno. Um sólido mercado acionário permitirá a integração banco-indústria, dando liquidez ao primeiro e uma boa estrutura de capitais ao segundo (Mundo Econômico, ago. 1971).

As autoridades econômicas prosseguiram durante algum tempo agitando o tema. O crescimento acelerado apontando para a Nação-Potência (no ano 2000), com um papel decisivo reservado ao setor privado nacional, colocava um desafio. Segundo Delfim:

Porque é este o momento em que teremos de aceitar o desafio de correr o risco de criar grandes unidades econômicas, que, com os riscos que lhe são inerentes, serão os instrumentos de construção do poder nacional brasileiro. ${ }^{37}$

A conglomeração, seguindo-se ao fortalecimento do sistema bancário-financeiro, constituía um atalho para enfrentar com êxito o desafio colocado. A magnitude do esforço de investimento em perspectiva amplificava a importância fundamental reservada ao sistema financeiro. O diretor do Banco Central para a área bancária sinalizava a resposta esperada pelas autoridades:

O sistema financeiro privado, aliado ao oficial, deverá se aparelhar para fornecer os insumos necessários a essa reforma, cumprindo-lhe colocar à disposição da economia, vultosos financiamentos a longos prazos e taxas compatíveis, ou, ainda, participar diretamente dos investimentos. À função clássica dos bancos comerciais, como intermediadores de capital de giro, há de se somar a de empreendedor. ${ }^{38}$

E deve ser ressaltado que o aspecto essencial da proposta de conglomeração residiu no objetivo reiterado de "construção do poder nacional

(37) Ver "Doze bodes e um leão" (Jornal do Brasil, 31 mar. 1972). mar. 1972)

(38) Ver Luiz de Carvalho e Mello Filho, "Ao longo do tempo a concentração" (Jornal do Brasil, 31 
brasileiro" (segundo a linguagem da ESG), o que exigia a constituição da grande empresa privada nacional. Tal preocupação não refletia qualquer resquício de xenofobia nem tampouco constrangimento em face do crescimento da empresa estatal. Fortalecimento da empresa privada nacional, sem qualquer veto à atuação dos sócios Estatal/Multinacional, visando a conformar uma estrutura dotada de maior estabilidade na marcha para a Nação-Potência. José Flávio Pécora, secretário-geral do Ministério da Fazenda, observaria a respeito: Parece-nos importante que haja grupos privados brasileiros, grandes, que levariam o sistema a uma situação de equilíbrio mais desejável. ${ }^{39}$

Outro integrante da equipe de Delfim propiciaria uma das mais claras manifestações do projeto ambicionado:

Creio que não há condições de se repetir no Brasil a experiência japonesa... Não é isso o que desejamos. A idéia é a seguinte: temos a grande empresa governamental... Ao mesmo tempo, observamos que existem grandes empresas industriais de capitais externos e um número reduzido - meia dúzia - de grandes empresas industriais nacionais. O que existe de grande no setor privado brasileiro é a área bancária mais concentrada e mais poderosa. Qual a filosofia que funcionou através de toda a legislação relativa ao banco comercial nos últimos 20 ou 30 anos? Para evitar o risco do monopólio, obrigava-se os bancos comerciais a restringir sua participação direta em outras empresas. O que se começa a aprender? É fundamental a associação das instituições financeira e fabril. Dá-se chance a que grupos poderosos nacionais possam vir tornar-se cabeças de grandes grupos nacionais que se contraporão às grandes empresas estatais e às grandes empresas estrangeiras que aqui estão operando. ${ }^{40}$

Diante da controvérsia ainda reinante acerca de quem seria o agente articulador do conglomerado, o assessor de Delfim revelava a preferência latente na Fazenda pelos bancos comerciais:

O que nós estamos querendo criar são os conglomerados nacionais. Os bancos comerciais têm condições de liderar esse agrupamento de empresas, porque nelas está assegurada a hegemonia do capital nacional. Não é, entretanto, compulsória a formação de conglomerados nem que o banco comercial deve ser a cabeça. $\mathrm{O}$ governo tem sido extremamente pragmático. É necessário, entretanto, reconhecer que existe num banco comercial um poder gerencial que o habilita a tornar-se cabeça do grupo e nada mais. ${ }^{41}$

(39) Ver seu pronunciamento no Simpósio sobre Fusões e Incorporações, de dezembro de 1971 (Febraban/Idort, 1972, p. 22-23). Delfim Netto referiu-se explicitamente ao objetivo de construção do poder nacional em seu artigo no Jornal do Brasil (31 mar. 1970).

(40) Declaração de Eduardo Pereira de Carvalho, chefe da Assessoria Econômica do Ministério da Fazenda, em mesa-redonda promovida pelo Jornal do Brasil (31 mar. 1972).

(41) Cf. Jornal do Brasil (31 mar. 1972). Ver também a matéria, com ares de uma exposição semioficial, "O longo caminho do truste ao conglomerado, rumo ao desenvolvimento" (Mundo Econômico, ago. 1971, p. 42-48). Aí se observa que, fomentadas diretamente por assessores ministeriais, em caráter reservado, as especulações alçavam vôos mais altos: sonhava-se com uma integração do tipo Bradesco-Votorantim ou Nacional de MG-Matarazzo, visando ao surgimento da grande empresa privada nacional. 
Uma apreciação adequada do alcance do projeto delfiniano requer o reconhecimento do caráter complexo da política econômica. Durante a ditadura, a política econômica, além de mediar/canalizar interesses (supostamente de forma desbalanceada), tinha de responder a demandas de natureza político-ideológicas oriundas da forma específica assumida pelo regime. Assim, um documento utilizado nos cursos da ESG, em 1971, fazia referência ao "desenvolvimento insuficiente da empresa nacional em face da empresa estrangeira e da estatização" e apontava "a necessidade de se evitar que, algum dia, investimento privado signifique investimento estatal". O documento concluía - como se estivesse antecipando o risco de ocorrer uma tal tendência - “... se um dia tais perspectivas se concretizarem, as inevitáveis desapropriações nos levarão qualitativamente a desfigurar um desenvolvimento que já é, quantitativamente, bastante animador". ${ }^{42}$ Vale dizer, os estrategistas do regime viam riscos de enfraquecimento do "poder nacional", inviabilizando a obtenção dos "objetivos nacionais", sintetizados na busca da Nação-Potência. Ou, alternativamente, um resultado comprometedor da estratégia adotada (enquanto "arte de preparar $e$ aplicar o poder nacional"), pois inteiramente em dissonância com o objetivo final almejado que não admitia nem um controle indiscriminado do capital estrangeiro sobre a economia nem a estatização alastrada. Daí a importância da grande empresa privada nacional, um contrapeso necessário para evitar (ou minimizar) aqueles riscos. O projeto do conglomerado era uma resposta a essa demanda.

Por outro lado, a promoção da grande empresa apoiava-se em um pressuposto de ordem econômica: a crença na existência de uma forte correlação entre concentração e eficiência, antecipando-se uma tendência à redução de custos e maior competitividade (inclusive no mercado externo). Nesse sentido, argumentava uma autoridade da Fazenda:

Nossas empresas estão numa fase em que, pela sua dimensão, podem estar e estarão obtendo um custo decrescente. Isto é uma vantagem para elas e para a sociedade e aí surge a motivação do governo em estimular o processo iniciado pelos empresários de juntar organizações para obter melhor tamanho. ${ }^{43}$

O projeto de conglomerado, embora fracassado, não foi de forma alguma uma manifestação apenas retórica. É verdade que a grande reforma bancária em

(42) Ver Segurança e Desenvolvimento (n. 148, p. 49-51, 1972). Segundo o Manual Básico da ESG (1975): "Poder nacional é a expressão integrada dos meios de toda ordem de que dispõe efetivamente a Nação, numa época considerada, para promover, sob a direção do Estado, no âmbito interno e externo, a consecução ou manutenção dos Objetivos Nacionais".

(43) Ver José Flávio Pécora, "Política do governo para as fusões" (Indústria e Desenvolvimento, p. 14, fev. 1972). Ver também seu artigo no Jornal do Brasil (31 mar. 1972). Note-se que a concentração não seria absoluta, não se prevendo o desaparecimento da pequena e média empresa. Segundo Delfim Netto: “.... existe lugar para todas as empresas - pequenas, médias e grandes. O que não existe é lugar para empresas ineficientes" (Banas, 16 ago. 1971, p. 7). E ainda J. F. Pécora: "O Governo vê na grande empresa uma parte do sistema de produção e não a única peça do sistema de produção" (Febraban/Idort, 1972, p. 24). 
perspectiva não se materializou. Porém um elenco de medidas preparatórias tomou forma no período, atestando o desejo das autoridades de saltar rapidamente das intenções para a introdução de modificações efetivas. Cabe registrar:

- Resolução 178, de 09 de março de 1971, autorizando os bancos de investimento a aumentarem suas aplicações em bens de ativo fixo de $10 \%$ para $30 \%$ do capital e reservas.

- Circular 159, de 20 de maio de 1971, redefinindo o conceito de ativo imobilizado para os bancos comerciais, agora excluindo as participações acionárias em outras instituições financeiras (inclusive companhias de seguro). Outra circular, de número 161, de 30 de junho de 1971, incluiu as participações em companhias de seguros entre as imobilizações técnicas dos bancos comerciais.

- Resolução 184, de 20 de maio de 1971, estabelecendo: 1) redução de 0,5\% no depósito compulsório dos bancos comerciais para aplicação obrigatória em ações ou debêntures conversíveis de empresas não financeiras de capital não superior a 70.000 vezes o maior salário mínimo vigente; 2) manutenção em carteira desses títulos pelo prazo mínimo de dois anos (um ano, no caso de sociedade de capital aberto); 3) imposição de um limite para a participação acionária correspondente a $49 \%$ do capital da firma emissora dos títulos.

- Decreto-lei 1.182, de 16 de julho de 1971, concedendo isenção de imposto de renda incidente sobre a reavaliação de bens do ativo imobilizado no caso de operações de incorporação (fusão), exigindo como contrapartida a abertura do capital. O decreto corrigia um problema de ordem fiscal, detectado como um obstáculo ao desejado processo de concentração, sendo extensivo também a alguns casos de simples abertura de capital, sem incorporação. E para arbitrar as solicitações de benefício fiscal criou-se a COFIE - Comissão de Fusão e Incorporação de Empresas. ${ }^{44}$

- Lei 5.710, de 07 de outubro de 1971, regulamentada pela resolução 201, de 20 de dezembro de 1971, permitindo que a abertura de capital das instituições financeiras se fizesse através da emissão de ações preferenciais ao portador (sem

(44) Segundo J. F. Pécora, "Política do governo para as fusões" (Indústria e Desenvolvimento, p. 16, fev. 1972): “... pelo menos um elemento, de ordem fiscal, constituía entrave de certa importância à aglomeração: os registros contábeis das empresas consagravam valores de ativos imobilizados que, mesmo corrigidos monetariamente, ficavam aquém dos de mercado. As transações de fusão não podiam ser feitas porque ninguém iria entregar parte do patrimônio com valor aquém do real. E se o atualizasse ao valor do mercado teria de pagar Imposto sobre a Renda pela diferença”. Sobre a recém-criada COFIE, ele a descreveu nos seguintes termos: “... deixamos o decreto amplo e montamos uma Comissão que, caso por caso, analisa a situação particular, julga as conveniências, avalia os problemas e exara um pronunciamento. É tão discricionário o poder dessa Comissão, que ela pode tomar decisões diferentes em casos iguais, ou decisões iguais em casos diferentes, uma vez que ela vai procurar atender a razões de interesse econômico que a ela e ao Ministro da Fazenda caberá julgar" (Febraban/Idort, 1972, p. 25-26). 
direito a voto) até o limite de 50\% do capital (a regra anterior estabelecia 100\% de ações nominativas).

- Resolução 250, de 15 de março de 1973, reduzindo uma nova parcela de 0,5\% do depósito compulsório dos bancos comerciais para aplicação obrigatória na subscrição de ações ou debêntures conversíveis de empresas comerciais exportadoras (as "trading companies", recém-criadas como parte de um esforço mais agressivo da ofensiva exportadora que caracterizou o período).

Essas medidas apenas constituem uma indicação do comprometimento efetivo da política econômica com o projeto da conglomeração, não configurando nenhum avanço real nesse sentido. Para isso, os agentes maiores da conglomeração teriam de dar mostras do seu engajamento no processo, o que não ocorreu. Assim, por exemplo, o Decreto-lei 1.182 acabou favorecendo um processo de concentração e conglomeração de escopo limitado: a COFIE aprovou em 1972-1973 cerca de 29 processos de fusão e incorporação na área das seguradoras, um segmento cobiçado pelos conglomerados bancários. Enquanto a resolução 184, cercada de grande expectativa quando de seu anúncio - as autoridades monetárias haviam comunicado aos banqueiros que, tão logo utilizada, uma liberação adicional de 1,5\% seria disponibilizada - gerou resultados decepcionantes. Em 1971, 55,4\% dos recursos foram usados pelos bancos para expandir a centralização na sua área preferencial (turismo, hotéis, outros serviços), contra 39\% direcionados à indústria e 5,6\% em atividades agropecuárias. A promessa de ampliar a liberação do compulsório foi abandonada - e quando sobreveio na forma da resolução 250 não despertou o entusiasmo dos banqueiros. $^{45}$

Na verdade, o projeto de conglomerado - qualquer que seja a avaliação da sua importância do prisma do desenvolvimento de um capitalismo como o brasileiro - foi além dos interesses concretos das frações empresariais dominantes. Sem pretender que isso constitua uma prova factual, não deixa de ser muito significativo que lideranças empresariais conhecidas da área bancária, chamadas a posicionar-se no debate, não tenham tido qualquer reserva em opinar negativamente. A opinião dominante entre os banqueiros era a favor de uma conglomeração restrita, abarcando o próprio sistema financeiro e segmentos da área de serviços (a tendência que se materializou rapidamente), enquanto a ambicionada integração com a indústria devia ser evitada ou, quando muito, delegada aos bancos de investimento (uma curiosa forma de negação do projeto, dada a perda de importância dos bancos de investimento independentes). A

(45) Um banqueiro assim responderia à nova iniciativa: "Não sou um comerciante, nem que me ensinem; sou um homem de finanças, um banqueiro. Não se pode confundir as coisas: o que aconteceu lá fora foi que alguns traders, com o sucesso de seus empreendimentos, viraram banqueiros" (Vidigal, in Banas, 01-08-73). Ver também: Mundo Econômico, agosto/1971, p.42-48; Banas Financeiro 1972/1973, p.145; Indústria e Desenvolvimento, janeiro/1972 ("Bancos sob o signo da concentração"). 
resposta direta de Ruy de Castro Magalhães, do Banco Comércio e Indústria de Minas Gerais, talvez seja a melhor síntese do pensamento disseminado entre os banqueiros:

Eu talvez não compreendesse que o conglomerado bancário se compusesse também de empresas industriais. O conglomerado pode existir, mas em termos de especialização financeira... Eventualmente a gente recebe ações que significam o controle de uma indústria, mas não para conservá-las. É risco que banco nenhum pode correr. ${ }^{46}$

\section{Conclusões}

A integração banco-indústria, peça importante da estratégia de desenvolvimento do governo Médici, não vingou. Não terá sido por falta de convicção das autoridades econômicas que o projeto se mostrou inviável. Mas é fora de dúvida que um notável processo de concentração na área bancária e sua expansão para outras faixas de atividade ocorreu, transfigurando substancialmente a fisionomia do sistema financeiro. Esse processo, certamente desatado pela dinâmica da acumulação financeira, foi determinado em medida não desprezível pela mudança de orientação da política econômica para o setor a partir de 1967. Como negar tal inflexão diante do flagrante contraste entre o projeto liberal da reforma financeira de Campos-Bulhões e o projeto de conglomerado articulado por Delfim Netto? No curto espaço de alguns anos, os bancos comerciais passaram de uma obscura posição residual, tendo assegurado não mais que a sua sobrevivência vegetativa, a núcleo articulador da futura grande empresa privada nacional, entidade tida por essencial na marcha rumo à Nação-Potência nos marcos do capitalismo associado.

Por que o desinteresse dos bancos comerciais, frustrando as expectativas dos formuladores do projeto? Uma resposta, muito comum, enfatiza o papel da inflação crônica: nesse ambiente, um estado de incerteza aguçada tenderia a inibir a predisposição dos bancos a se envolverem em operações de longo prazo. Essa explicação, ainda que não deva ser menosprezada, afigura-se parcial. Por que razão o horizonte embaçado criado pela inflação atemorizou os empresários da área bancária diante dos riscos do longo prazo, mas não teve o mesmo efeito sobre os empresários industriais, os quais se lançaram em vigorosa onda de investimentos? Uma aversão enraizada ao risco envolvido nas aplicações de longo

(46) Ver Banas (13 mar. 1972). Ver também as manifestações, no mínimo reticentes, de Olavo Setúbal, do Itaú (Banas, 15/22 mar. 1971), de Aloysio Faria, do Real (Jornal do Brasil, 31 mar. 1972 e Banas Financeiro (1973-1974, p. 341), de Roberto Gouvea, do Bamerindus (Jornal do Brasil, 31 mar. 1972 e Banas, 27 set. 1971), de Sergio Mellão, do Comercial-Brasul (Banas, 13 set. 1971) e de Gastão B. Vidigal, do Mercantil de SP (Banas, 01 ago. 1973). Em sentido contrário, uma defesa e um lúcido entendimento do projeto de conglomerado encontrase em declarações de Valter Moreira Sales, do Unibanco (Jornal do Brasil, 31 mar. 1972 e Mundo Econômico, ago. 1971) e de Gerdau Johannpeter, do Grupo Gerdau (Jornal do Brasil, 31 mar. 1972). 
prazo parece uma descrição aceitável do padrão de comportamento dos bancos comerciais no Brasil. De qualquer forma, essa característica tendeu a ser reforçada à medida que vicejavam amplamente oportunidades sumamente atrativas de lucratividade envolvendo operações de natureza meramente "cartorial" ou mesmo abertamente especulativa. Durante o ciclo expansivo (e no restante da década), tal foi o caso das operações de intermediação de recursos externos através da Resolução 63, as quais exibiram um forte crescimento ao mesmo tempo em que a política econômica procurou eliminar quaisquer riscos para a instituição intermediária. E com a aceleração inflacionária pós-1973 entrou-se num ciclo prolongado de rentáveis operações de curtíssimo prazo, na intermediação de "dinheiro financeiro", evoluindo para um estado de paroxismo na década de 1980. Aqui é possível identificar um conteúdo mais plausível no argumento de que a inflação crônica esteve na raiz do fracasso do projeto de conglomerado.

Por outro lado, em seu movimento sempre descontínuo, não-linear, a política econômica do regime militar abandona o projeto de conglomerado com a mudança de administração em 1974. A diretiva de fortalecimento da empresa privada nacional visando a corrigir um acentuado desbalanceamento da organização industrial é mantida e inclusive ganha maior destaque - mas a estratégia adotada é outra. Não obstante, o projeto perseguido durante a administração anterior de Médici continuou ecoando no II PND, dada a tendência da retórica do regime de ocultar quebraduras, divergências, construindo uma imagem (falsa) de continuidade inaugurada em 1964. E nesse sentido o II PND, ao preservar a idéia num conjunto variado de linhas de ação visando àquele objetivo maior, confirma que o projeto de conglomerado constituiu-se efetivamente num capítulo da política econômica do regime.

Igualmente cabe observar que os movimentos de concentração e centralização observados, particularmente de 1967 a 1974, não terão continuidade nas décadas subseqüentes. Crises bancárias e financeiras (iniciadas já em 1974 e reproduzidas nos anos 1980 e 1990), novamente expansão desenfreada de agências insuflada pela busca de "receita inflacionária", proliferação de bancos a partir da regulamentação do banco múltiplo, abertura do setor para o capital estrangeiro com uma tendência embrionária à desnacionalização - são exemplos de traços característicos do setor aflorados no período pós-1974. Não é impossível que uma política bancária nos moldes da examinada neste artigo venha novamente a ser dominante. Mas é um fato que ela foi ganhando um contorno distinto nos dois períodos subseqüentes, de inflação cronicamente alta até 1994 e de desinflação bem-sucedida desde então. 


\section{Bibliografia}

ALMEIDA, J. S. G. As reformas financeiras de 1964-65: objetivos, rumos e desvios. Rio de Janeiro: IEI/UFRJ, 1984. (Texto para Discussão, n. 59).

ASSIS, J.C. A chave do tesouro. Rio de Janeiro: Paz e Terra, 1983.

BANCO CENTRAL. Relatório Anual. 1972.

Relatório Anual. 1973.

Relatório Anual. 1976.

BOUZAN, A. Os bancos comerciais no Brasil. Tese (Doutorado)-São Paulo, 1972.

CARVALHEIRO, N. Bancos comerciais no Brasil: 1964-1976. Crescimento e Concentração. Dissertação (Mestrado)-FIPE/USP, São Paulo, 1982.

COMISSÃO DE VALORES MOBILIÁRIOS - CVM. Sistema de Intermediação de Valores Mobiliários. Rio de Janeiro: CVM, 1979.

COSTA, F. N. Bancos em Minas Gerais (1889-1964). Dissertação (Mestrado)-Instituto de Economia, Unicamp, Campinas, 1978.

DELFIM NETTO, Antonio; FREITAS, Luiz Mendonça de; STILMAN, Meyer. $O$ problema das financeiras no Brasil. [s.n.t.]. p. 36. Mimeografado.

DYMSKI, G. A. The Bank Merger Wave. Armonk, New York: M. E. Sharpe, 1999.

FISHLOW, A. Algumas reflexões sobre a política econômica brasileira após 1964. Estudos CEBRAP, São Paulo, n. 7, jan./mar. 1974.

FEBRABAN/IDORT. Simpósio sobre Fusões e Incorporações. São Paulo: Mestre Jou, 1972 .

IANNI, O. Estado e planejamento econômico no Brasil (1930-1970). Rio de Janeiro: Civilização Brasileira, 1977.

LESSA, C. A estratégia de desenvolvimento 1974-1976: sonho e fracasso. Campinas: Unicamp. IE, 1998.

MACARINI, J. P. A política econômica do governo Médici: 1970-1973. Nova Economia, v. 15, n. 3, set./dez. 2005.

PORTOCARRERO DE CASTRO, H. O. As causas econômicas da concentração bancária. Rio de Janeiro: IBMEC, 1981.

SILVA, A. M. Intermediação financeira. São Paulo: FIPE/USP, 1980. Mimeografado.

SOCHACZEWSKI, A. C. Financial and economic development of Brazil, 1953-1968. London School of Economics and Political Science. Tese (Doutorado). 1980.

TAVARES, M. C. Da substituição de importações ao capitalismo financeiro. Rio de Janeiro: Zahar, 1974.

VIDIGAL, G. E. B. Bancos e finanças: aspectos da política financeira brasileira. São Paulo: Federação Nacional dos Bancos, 1981.

WANDERLEY, C. A.; PIMENTEL, R. B. O caminho brasileiro dos bancos de investimento. Cadernos Halles, n.,5, 1970. 